The Effect of Bacterial Applications on Resource Utilization in Strawberry (Fragaria $x$ ananassa duch) Production

\author{
Tuğçe SELVİ1 ${ }^{1}$, Ahmet EşITTKEN², Zeki BAYRAMOĞLU ${ }^{3}$, Mesude Figen DÖNMEZ ${ }^{4}$ \\ ${ }_{1,2}$ Selcuk University, Agricultural Faculty, Department of Horticultural Science Konya, ${ }^{3}$ Selcuk University, Agricultural Faculty, Department \\ of Agricultural Economics, Konya, ${ }^{4}$ Igdır University, Agricultural Faculty, Department of Plant Protection, Iğdır \\ ${ }^{1}$ https://orcid.org/0000-0001-9107-4563, ${ }^{2}$ https://orcid.org/0000-0002-6140-7782, ${ }^{3} \mathrm{https}: / /$ orcid.org/0000-0003-3258-3848 \\ ${ }^{4} \mathrm{https}: / /$ orcid.org/0000-0002-7992-8252 \\ 凶: zbayramoglu@selcuk.edu.tr
}

\begin{abstract}
In this study, the effect of bacterial application on input utilization in strawberry cultivation was investigated. The study was carried out with Festival strawberry varieties in unheated farmer greenhouse in Antalya. In the research, the farmer application was taken as a control and the amount of NPK (Nitrogen, Phosphor, Potassium) fertilizer used by the farmer was reduced by $33 \%$ and $66 \%$. In addition, Rhizobium SY55 with fixing feature of N, Bacillus SK63 with Psolving property and Herbaspirillum SY48 bacterial strains with Kfixing were applied to the root region of half of the strawberry plants at each fertilizer level by mixing 1: 1: 1 ratio. In the study, yield per plant and per decare was determined, the amount and costs of fertilizer used per decare, and per plant were calculated. According to the results, bacterial application decreased amount of fertilizer used and costs and increased the productivity per unit. The increase in income due to the increase in productivity was also determined. In addition, products increased the market competitiveness due to the increase in revenue by reducing the production costs. With these characteristics of bacterial application, it can be said that it is suitable to the universal principles of sustainable agriculture.
\end{abstract}

\title{
Çilek Üretiminde Bakteri Uygulamalarının Kaynak Kullanımına Etkisi
}

\section{ÖZET}

$\mathrm{Bu}$ çalışmada çilek yetiştiriciliğinde bakteri uygulamasının girdi kullanımı üzerindeki etkisi araştırılmıştır. Çalışma Antalya'da ısıtmasız çiftçi serasında Festival çilek çeşidi ile yürütülmüştür. Araştırmada çiftçi uygulaması kontrol olarak alınmış ve çiftçinin kullandığ 1 NPK gübre miktarı \%33 ve \%66 oranlarında azaltılarak gübreleme yapılmıştır. Ayrıca, N fiksetme özelliğine sahip Rhizobium SY55, P çözme özelliğine sahip Bacillus SK63 ve K çözme özelliğine sahip Herbaspirillum SY48 bakteri ırkları 1:1:1 oranında karıştırılarak her gübre seviyesinde bulunan çilek bitkilerinin yarısının kök bölgesine uygulanmıştır. Araştırmada bitki başına ve dekara verim belirlenmiş, dekara gübre kullanım miktarı ve maliyetleri, dekara ve bitki başına gelir hesaplanmıştır. Elde edilen sonuçlara göre bakteri uygulamasının gübre kullanım miktarını ve masraflarını azalttığı ve birim başına verimi artırdığı belirlenmiştir. Verim artışına bağlı olarak gelir artışı da belirlenmiştir. Ayrıca üretim maliyetlerini azaltarak gelir artışını sağlaması nedeniyle ürünlerin pazar rekabet gücünü artırdığı belirlenmiştir. Bakteri uygulaması bu özellikleri ile sürdürülebilir tarımın evrensel prensiplerine uygun olduğu söylenebilir.

\section{Research Article}

$\begin{array}{ll}\text { Article History } & \\ \text { Received } & : 11.10 .2019 \\ \text { Accepted } & : 24.02 .2020\end{array}$

Keywords
Bacterial Application
Bioeconomics
Rizobacteria

\section{Araştırma Makalesi}

$\begin{array}{ll}\text { Makale Tarihçesi } \\ \text { Geliş Tarihi } & : 11.10 .2019 \\ \text { Kabul Tarihi } & : 24.02 .2020\end{array}$

Anahtar Kelimeler
Bakteri Uygulaması
Biyoekonomi
Rizobakteri

Anahtar Kelimeler

Rizobakteri

To Cite : Selvi T, Eşitgen A, Bayramoğlu Z, Dönmez MF 2020. The Effect of Bacterial Applications on Resource Utilization in Strawberry (Fragaria x ananassa duch) Production. KSU J. Agric Nat 23 (5): 1308-1313. DOI: 10.18016/ ksutarimdoga.vi.631957. 


\section{INTRODUCTION}

The most basic needs of society is nutrition, which is met by agricultural products. The increase in the economic welfare of society along with the world population has increased the demand for agricultural products. While the adequacy of the existing agricultural production to the world population has been discussed; it is also estimated that the world population could be 9.5 billion in 2050 . Therefore, it is predicted that sufficiency problem of agricultural products will continue in the future. To meet the demand for agricultural products, which is predicted to increase in the future, has accelerated the research in this area. As a matter of fact, especially in developed and developing countries, arable agricultural lands have reached its final limit. Therefore, increasing productivity in the unit area is the most important solution to meet the demand for agricultural products and this situation increases the need for technology in production. In the last 50 years, significant productivity increases was realized in two main areas of agricultural production activity namely plant and animal production. For example; in wheat production "which has a strategic importance" in the EU 172.8\%, $224.2 \%$ yield increase is seen in Turkey in relative last 50 years. In the same way, milk has an important role in nutrition and has increased its production in the EU and Turkey by $199 \%$ and $230.1 \%$, respectively, in the last 50 years (Semerci, 2016). For this purpose, resources have been transferred for research and development activities, especially in developed countries. In fact, the ratio of research and development activities to GDP is $1.9 \%$ in the EU, $2.88 \%$ in the USA, $3.36 \%$ in South Korea, $1.24 \%$ in Russia and $4.28 \%$ in Israel (OECD, 2014). The increase in productivity is realized due to the developments in the use of chemical input and mechanization in the 1970s, which was named as the green revolution in terms of agricultural production. Industrial agriculture has started for many countries. However, the environmental impacts of the chemical inputs used in 2000s and their effects on human health was discussed. These situations was discussed in many studies, especially, carcinogenic effects of nitrogenous fertilizers, air pollution caused by the emergence of nitrogen oxide gases and pollution of underground water resources due to the contamination of the use of chemical input (Taşkaya, 2004; Sönmez ve ark., 2008).

After this period, although it is sensitive to the environment and human health, it has accelerated the research on the use of inputs to ensure efficiency in the unit area. In other words, biotechnological research was started to minimize the use of chemical inputs. Provided biotechnological studies added value by increasing the production capacity of agricultural production materials, while enabling the use of biological materials in non- agricultural areas (health, industrial etc.). For example, in the United States, the contribution of genetically modified agricultural products to national income exceeds 110 billion dollars, and the contribution of the country to national income exceeds 75 billion by the use of biological materials in production of medicines (Bayramoğlu et al., 2018; Biodesic, 2011; Kiper, 2012). In this field, genetic studies in plant production materials, breeding studies and hybridization are the most well-known methods but biological materials were used as input as well. In recent years, rhizobacteria are the most frequently emphasize on the biological materials. These bacteria are called "Plant Growth Promoting Rhizobacteria (PGPR)" Kloepper et al. (1980), the rhizosphere layer of the soil is the habitat for these organizms. These bacteria can promote plant root growth directly and indirectly, fix free nitrogen, dissolve phosphorus and potassium, make microelements useful by producing organic acid, provide plant growth by producing enzyme and phytohormone, increase water and mineral intake, provide systematic durability in plant, and they have the ability to be used as a biological fertilizer together with the suppression of the pathogen development. (Kloepper et al., 1980; Imriz et al., 2014). Especially with the studies on this bacteria, high nutritional value and value added, healthy products are grown and as a result of this, profitability of enterprises increase. In these studies, it was determined that these bacteria had many effects on the plant. Ma VD.(2011), Vani and Khan (2010), heavy metals detoxification of rizobacteria, Ahemad and Khan (2012), decomposition of pesticides, Mayak et al. (2004), salinity tolerance, Hynes et al. (2008) and dusty et al. (2012), biological struggle of plant diseases and pests, Çakmakci (2009), use of nutrient elements and minarets by plant, Dejordjevic et al., (1987) and Ferreira (1987) have conducted studies to support plant growth by producing phytohorman and enzyme. In addition, in sugar beet (Çakmakçı et al., 1997), barley and wheat in yield (Ozturk et al., 2003) and nitrogen intake in the barley, stem and body weight increase has been seen (Canbolat et al., 2006). Thus, the use of biological materials as inputs is important in protecting environmental sensitivity and human health, and it is seen that the biological materials used for input contribute to the increase of productivity. (Annapurna et al., 2011). Biotechnological studies are called knowledge-based production because they require high use of information. The studies to determine the value added as a result of biotechnological studies have entered the literature as a knowledge-based economy or bioeconomics in 1997. Bioeconomics have been defined differently according to the sectors which countries give importance. (Anonymous, 2019). For example, while the United States focuses on green, blue and white bioeconomics, 
the European Union focuses developments in field of health named as white bioeconomics. Bioeconomics in terms of agricultural production, also called green bioeconomics; taking into account the parameters that make up the yield and quality, and using all kinds of natural sciences and engineering services within the agricultural ecosystem, value added as a result of the use of technologies used in the production of plants, animals and microorganisms (Bayramoğlu et al. 2018). Although there are many studies showing (Eşitken et al., 2002, 2003, 2006, 2010; Orhan et al., 2006; Karlıdağ et al., 2007) PGPRs increase yields in many plants (Xu et al., 2011; Turan et al., 2010: Han and Supanjani, 2006: Yasmin et al., 2007). they reduce input use or increase the efficiency of the inputs used are quite limited. The effects of bacteria application on yield and input usage in strawberry production were investigated in the scope of this study.

\section{MATERIALS and METHOD}

The data used in the study were obtained from an experiment conducted with Festival strawberry varieties in non-heated greenhouse in Serik district of Antalya between October 2017 and June 2018. Festival is a short-day variety with fruits of conical shape and light red inside and dark and bright red outside. Although the aroma of the fruits is not as good as Sweet Charlie, yet, better than Camarosa. The fruit quality and yield of this variety are very similar to Camarosa. It is earlier variety than Camarosa (Türemiş and Ağaoğlu, 2013). Frigo seedlings were planted in triangle manner with a distance of $15 \mathrm{~cm}$ at the beginning of October and bacterial applications were made to root areas with drip irrigation in December, January and February. Applications in the greenhouse were carried out in accordance with general farming principles. Farmer application was taken as a control and fertilization was done by decreasing the amount of NPK fertilizer used by the farmer by $33 \%$ and $66 \%$. In addition, Rhizobium SY55 with fixing feature of $\mathrm{N}$, Bacillus SK63 with $\mathrm{P}$-solving property and Herbaspirillum SY48 bacterial strains with $\mathrm{K}$-resolving property were applied at the rate of $108 \mathrm{CFU} / \mathrm{ml}$ and 1:1: 1 were applied to the root region of half of the strawberry plants at each fertilizer level. Fertilizer application in the experiment was given by drip irrigation weekly divided throughout the season. The applications in the experiment are as follows.

1. Control (farmer application, $42.09 \mathrm{~kg} / \mathrm{da} \mathrm{N}, 31.94$ $\mathrm{kg} / \mathrm{da} \mathrm{P} 2 \mathrm{O} 5,51.98 \mathrm{~kg} / \mathrm{da} \mathrm{K} 2 \mathrm{O})$

2. Reduced 33\% (28.15 kg / da N, $21.29 \mathrm{~kg} /$ da P2O5, $34.78 \mathrm{~kg} / \mathrm{da} \mathrm{K} 2 \mathrm{O})$

3. $66 \%$ reduced $(14.20 \mathrm{~kg} / \mathrm{da} \mathrm{N}, 10.64 \mathrm{~kg} / \mathrm{da} \mathrm{P} 2 \mathrm{O} 5$, $17.57 \mathrm{~kg} / \mathrm{da} \mathrm{K} 2 \mathrm{O}$

4. Control + bacteria application

5. $33 \%$ reduced + bacteria application

6. $66 \%$ reduced + bacterial application
In the study, the amount of fruit harvested during the cultivation period was divided by the number of plants in the parcel and fruit yield per plant was determined. In addition, yield per hectare of fruit yield per plant was calculated. In addition, yield, input cost and income differences are calculated between fertilizer and bacteria applications. Because other inputs used in the production of strawberries were considered as fixed, only the changes in fertilizer costs were taken into consideration. Strawberry income per plant was multiplied by the yield obtained per plant $(0,37$ $\mathrm{USD} / \mathrm{kg}$ ). Strawberry income was calculated by dividing the strawberry income obtained by the fertilizer cost per decare and the strawberry income per unit of the input was calculated by dividing the strawberry yield per decare to the amount of fertilizer used. The monetary values used in the study were determined as TL and then converted to USD. The average monthly exchange rate was taken between the January - June 2018 as Dollars / Turkish Lira.

\section{RESULTS and DISCUSSION}

Table 1. presents the relationship between the inputoutput relationship and the cost-income relationship as a result of different levels of input utilization and bacterial application in strawberry production. According to this control group, $42.09 \mathrm{~kg} / \mathrm{da} \mathrm{N}, 31.94$ $\mathrm{kg} / \mathrm{da} \mathrm{P} 2 \mathrm{O} 5$ and $51.98 \mathrm{~kg} / \mathrm{da} \mathrm{K} 2 \mathrm{O}$ were applied and per decare $\$ 71.78$ fertilizer costs were realized. Per decare $4792.20 \mathrm{~kg}$ yield and $\$ 1757.53$ income were obtained with this cost. Average yield per input was $38,03 \mathrm{~kg}$ and income for $\$ 1$ fertilizer cost was $\$ 24.48$.

In the second application, the amount of fertilizer given in the control group was combined with the application of bacteria. As a result of this application, total fertilizer cost was $\$ 71,78 \mathrm{TL} / \mathrm{da}$. In return of this cost the obtained yield was per decare $7004.4 \mathrm{~kg}$ and the income was per decare $\$ 2568,85$. The yield per unit of the fertilizer used was $55.59 \mathrm{~kg}$ and the obtained income for one dollar of the fertilizer cost was $\$ 37.79$.

In the third group, the amount of fertilizer applied in the control group was reduced by $33 \%$. In this case, the fertilizer cost per decare was realized as per decare $\$ 47,98$. In return of this cost the obtained yield was calculated as $4485 \mathrm{~kg}$ per decare and the income was calculated as per decare $\$ 1644,87$. In this group, the revenue per capita and the average yield decreased compared to the second application and increased compared to the first application control group.

In the fourth control group, bacterial application is also added in addition to the third control group. In other words, control group fertilizer application was reduced by $33 \%$ and bacterial application are performed. According to this application, the fertilizer cost per decare was calculated as per decare $\$ 47,98 /$ da, the yield was per decare $6219 \mathrm{~kg}$ and the income was 
calculated as per decare $\$ 2280,81$. Income and average yields per unit of expenses were higher than other groups.

In the fifth group, control group fertilizer applications were reduced by \%66, and as a result of this obtained per decare $\$ 41,25$ the fertilizer cost and $4307.4 \mathrm{~kg}$ yield and $\$ 1579,73$ income. The yield and obtained income were the lowest for all application groups.

Table 1. Physical and monetary results of bacterial application in strawberry production

Tablo 1. Cilek Üretiminde Bakteri Uygulamasının Fiziki ve Parasal Sonuçları

\begin{tabular}{|c|c|c|c|c|c|c|}
\hline $\begin{array}{l}\text { Application Group } \\
\text { (Uygulama Grubu) }\end{array}$ & $\begin{array}{l}\text { Control } \\
\text { (Kontrol) }\end{array}$ & $\begin{array}{l}\text { Control + Bacteria } \\
\text { (Kontrol+ Bakteri) }\end{array}$ & $\begin{array}{l}\text { Reduced } 33 \% \\
\text { (\%33 Azaltılmış) }\end{array}$ & $\begin{array}{l}\text { Reduced } 33 \%+ \\
\text { Bacteria } \\
\text { (\%33 Azaltılmıs } \\
\text { +Bakteri) }\end{array}$ & $\begin{array}{l}\text { Reduced } 66 \% \\
\text { (\%66Azaltılmış) }\end{array}$ & $\begin{array}{l}\text { Reduced } 66 \%+ \\
\text { Bacteria } \\
\text { (\%66 Azaltılmıs } \\
\text { +Bakteri) }\end{array}$ \\
\hline $\mathrm{N}(\mathrm{Kg})$ & 42.09 & 42.09 & 28.15 & 28.15 & 44.20 & 44.20 \\
\hline $\mathrm{P}(\mathrm{Kg})$ & 31.94 & 31.94 & 21.29 & 21.29 & 10.64 & 10.64 \\
\hline $\mathrm{K}(\mathrm{Kg})$ & 51.98 & 51.98 & 34.78 & 34.78 & 17.57 & 17.57 \\
\hline Total Fertilizer Cost $(\$)$ & 293.60 & 293.60 & 196.23 & 196.23 & 168.72 & 168.72 \\
\hline $\begin{array}{l}\text { Cost Change Based on } \\
\text { Control Group (\$) }\end{array}$ & 100.00 & 100.00 & -33.16 & -33.16 & -42.54 & -42.54 \\
\hline Yield per Plant (g) & 798.70 & 1167.40 & 747.60 & 1036.50 & 717.90 & 819.10 \\
\hline Income $(\$)($ Gelir $)$ & 1198.05 & 1751.10 & 1121.40 & 1554.75 & 1076.85 & 1228.65 \\
\hline $\begin{array}{l}\text { Change in Revenue per } \\
\text { Plant by Control Group } \\
\%\end{array}$ & 100.00 & 46.16 & -6.40 & 29.77 & -10.12 & 2.55 \\
\hline $\begin{array}{l}\text { Yield per Unit Area } \\
(\mathrm{kg} / \mathrm{da})\end{array}$ & 4792.20 & 7004.40 & 4485.00 & 6219.00 & 4307.40 & 4914.60 \\
\hline Income $(\mathrm{kg} / \mathrm{da})$ & 7188.30 & 10506.60 & 6727.50 & 9328.50 & 6461.10 & 7371.90 \\
\hline $\begin{array}{l}\text { Change in Revenue per } \\
\text { Plant by Control Group } \\
(\%)\end{array}$ & 100,00 & 46.16 & -6.41 & 29.77 & -10.12 & 2.55 \\
\hline Relative Profit Level & 24.48 & 35.79 & 34.28 & 47.54 & 38.29 & 43.69 \\
\hline $\begin{array}{lll}\text { Average } & \text { Yield } & \text { per } \\
\text { Input (kg) } & & \\
\end{array}$ & 38.03 & 55.59 & 53.25 & 73.84 & 59.49 & 67.87 \\
\hline
\end{tabular}

In sixth group, fertilizer application reduced $\% 66$ as control group and added bacteria application, as a result, for per decare $\$ 41,25$ fertilizer costs, per decare $4914,60 \mathrm{~kg}$ yield and $\$ 1802,42$ da income was obtained.

When we compare the all bacterial application groups it was determined that bacterial application caused more fertility and income increase with the same fertilizer cost. These yield increases were realized $\% 46.16$ in the second group according to first group, $\% 38.66$ in the fourth group according to third group, and \%14.09 in the sixth group according to fifth group. According to all application groups, bacterial application was found to cause an increase of \%32,97 on average. When the groups were compared, it was determined that the most profitable group was the fourth group. In this group, \%33 less fertilizer was used than the control group which is the fertilizer application of the producers. And also, in fourth group the fertilizer cost was \%33.16 lower than the producer group. However, the yield was \%41.73 and the income is \%29.77 higher. It was determined that bacterial applications not only increasing the producer income but also it reduced the costs related to input use. And as a result, it provides resource use efficiency. The average yield per unit of the input used in the bacterium-treated production groups and the average product yield per unit of the input was higher than that of non-bacterial trials (Table 1). Similar results were obtained in some of previous studies. Turan et al., (2010) found that artificial fertilization can be reduced by $50 \%$ in the production of wheat with the mixture of OSU-142, M3 and Azospirillum Sp245 isotra. Cakmak et al., (2012) studied using nitrogen fixator and phosphate-solvent bacteria in tea clones and the effects of food intake. They emphasized that some isotopes exhibit even more effective than biological fertilizers and that these isotypes have biological fertilizer. Baset Mia et al., (2010) had some application of PGPR to banana plants and they found two of those biological strains showing biological fertilizers potential. Yasmin et al., (2007) studied on potatoes with PGPR isolates applied different doses of fertilizer showing a biological improve PGPRs and have obtained the result of reducing the use of artificial fertilizers. Sultana and Pindi (2013) found four new PGPR isolates from the rhizosphere of cotton plants. They reported that these isolates caused an increase in the level of NPK. Annapurna et al. (2011) reported that PGPRs show different effects in single and combination applications. They stated that the combination application could be an environmentally friendly application on the performance and growth of wheat plant.

Bacterial application with the control group increased the efficiency per unit cost of the inputs used, as well 
as increasing the productivity in the unit area. Bacteria application increased the efficiency of inputs used in production.

\section{CONCLUSION}

It was determined that the results of bacteria application in strawberry cultivation decreased the use of chemical inputs and increased the productivity. As a matter of fact, the universal principle of the agricultural production is the productivity growth which is sensitive to the environment. It was also determined that the bacterial application used for input purposes was sensitive to the environment and increases the productivity per unit area and plant. These results were also important in terms of market competition of products. In fact, by taking high productivity from unit area or reducing costs will reduce unit costs and increase the competitiveness of the product in the market. Quality is another component of competition with price. Market competition can be useful for quality products that give importance to human health and sensitive to the environment. On the scope of this study, bacterial used for biological input, which is sensitive to human health and environment and has high productivity capability and cost minimization, is suitable to universal principles of sustainable agriculture.

\section{Statement of Conflict of Interest}

Authors have declared no conflict of interest.

\section{Author's Contributions}

The contribution of the authors is equal.

\section{REFERENCES}

Ahemad M, Khan MS 2012. Productivity of greengram in tebuconazole-stressed soil, by using a tolerant and plant growth-promoting Bradyrhizobium sp. MRM6 strain. Acta Physiol. Plant, 34: 245-254.

Annapurna K, Ramadoss D, Vithal L, Bose P, Sajad 2011. PGPR bioinoculants for ameliorating biotic and abiotic stresses in crop production. Proceedings of the 2nd Asian PGPR Conference, Beijing, China, pp:67-72.

Anonymous 2019. Yeşil Biyoekonomi. https://nacikgoz. wordpress.com/tag/yesil-biyoekonomi/ Erişim tarihi :01.02.2019.

Bayramoğlu Z, Ağıan K, Tekin M 2018. Türkiye'de Biyoekonomi Girişimciliğinin Tarımdaki Önemi. KSÜ Tarım ve Doğa Dergisi, Özel Sayı, 21(6): 213222.

Baset Mia MA, Shamsuddin ZH, Wahab Z, Marziah M 2010. Effect of plant growth promoting rhizobacterial (PGPR) inoculation of tissue-cultures Musa plantlets under nitrogen-free hydroponics condition. Australian Journal of Crop Science, 4(2): 85-90.
Biodesic 2011. Bioeconomy Update http://www.biodesic.com/library/Biodesic_2011_ Bioeconomy_Update.pdf (Erişim Tarihi: 12.02.2019).

Canbolat MY, Bilen S, Çakmakçı R, Şahin F, Aydın A 2006. Effect of plant growth-promoting bacteria and soil compaction on barley seedling growth, nutrient uptake, soil properties and rhizosphere microflora. Biology and fertility of soils, 42(4): 350-357.

Çakmakçi R, Kantar F, Algur ÖF 1999. Sugar beet and barley yields in relation to Bacillus polymyxa and Bacillus megaterium var. phosphaticum inoculation. Journal of Plant Nutrition and Soil Science, 162(4): 437-442.

Çakmakcı R 2009. Stres koullarında ACC deaminaz üretici bakteriler tarafindan bitki geliiminin teşvik edilmesi, Atatürk Üniversitesi Ziraat Fakültesi Dergisi, 40(1): 109-125.

Çakmakcı R, Ertürk Y, Dönmez MF, Erat M, Kutlu M, Sekban R, Haznedar A 2012. Azot fikseri ve fosfat çözücü bakterilerin Muradiye 10 çay klonunda gelime, verim ve besin alımı üzerine etkisi, Tarım Bilimleri Aratırma Dergisi, 5(2): 176-181.

Dejordjevic MA, Gabriel DW, Rolfe BG 1987. Rhizobium-the refined parasite of legumes. Annu. Rev Phytopathology, 25: 145-168.

Ferreira MCB, Fernandes MS, and Döberenier J 1987. Role of Azospirillum brasilense nitrate reductase in nitrate assimilation by wheat plants. Biol. And Ferti. of Soils, 4: 47-53.

Hynes RK, Leung GC, Hirkala DL, Nelson LM 2008. Isolation, selection, and characterization of beneficial rhizobacteria from pea, lentil and chickpea grown in Western Canada. Can. J. Microbiol. 54: 248-258.

İmriz G, Özdemir F, Topla İ, Ercan B, Taş MN, Yakışır E, Okur O 2014. Bitkisel Üretimde Bitki Gelişimini Teşvik Eden Rizobakteri (PDGR)'ler ve Etki Mekanizmaları, Elektronik Mikrobiyoloji Dergisi 12(2): 1-19.

Kiper M 2013. Biyoteknoloji Sektörel İnovasyon Sistemi: Biyoteknoloji Sektörel İnovasyon Sistemi Kavramlar Dünyadan Örnekler Türkiye'de Durum ve Çıkarımlar. Türkiye Teknoloji Geliştirme Vakfı (TTGV), 1.Baskı, 229s.

Kloepper JW, Leong J, Teintze M, Scrotch MN 1980. Enhanced plant growth by sideroph-ores produced by plant growth-promoting rhizobacteria, 885-886.

Ma Y, Rajkumar M, Vicente JA, Freitas, H 2011. Inoculation of endophytic bacteria on host and nonhost plant-effects on plant growth and Ni uptake. J. Hazard. Mater, 195(2011): 230-237.

Mayak S, Tirosh T, Glick BR 2004. Plant growthpromoting bacteria confer resistance in tomato plants to salt stress. Plant physiol. Biochem, 42(6): 565-572.

Ozturk A, Caglar O, Sahin F 2003. Yield response of wheat and barley to inoculation of plant growth 
promoting rhizobacteria at various levels of nitrogen fertilization. Journal of Plant Nutrition and Soil Science, 166(2): 262-266.

Samancıŏ̆lu A, Yıldırım E 2015. Bitki Gelişimini Teşvik Eden Bakteri Uygulamalarının Bitkilerde Kuraklığa Toleransı Artırmadaki Etkileri. Mustafa Kemal Üniversitesi Ziraat Fakültesi Dergisi, 20(1): 72-79.

Semerci A 2016. Tarımsal verimlilik düzeyleri ile Avrupa Birliği-Türkiye tarımı. Gaziosmanpaşa Üniversitesi Ziraat Fakültesi Dergisi (Journal of Agricultural Faculty of Gaziosmanpasa University) JAFAG, 33(3): 203-213.

Sönmez İ, Kaplan M, Sönmez S 2008. Kimyasal gübrelerin çevre kirliliği üzerine etkileri ve çözüm önerileri. Derim, 25(2): 24-34.

Sultana T, Pindi PK 2013. Assesment of PGPR bacteria of cotton fields, International Journal of Agricultural Science and Research, 3(1): 207-216.

Taşkaya B 2004. Tarım ve çevre. TC Tarım ve Köy İşleri Bakanlığı Tarımsal Ekonomi Araştırma Enstitüsü TEAE-Bakış, 5(1): 11-15.

Tozlu E, Karagöz K, Babagil GE, Dizikısa T, Kotan R 2012. Effect of some plant growth promoting bacteria on yield, yield components of dry bean (Phaseolus vulgaris L. cv. Aras 98). J Agric Faculty Atatürk Univ, 43(2): 101-106.
Turan M, Gulluce M, Cakmakci R, Oztas T, Sahin F, Gilkes RJ, Prakongkep N 2010. The effect of PGPR strain on wheat yield and quality parameters. Proceedings of the 19th World Congress of Soil Science: Soil solutions for a changing world, Brisbane, Australia, 209-212.

Türemiş, N. Ve Ağaoğlu, S. 2013. Çilek. Üzümsü Meyveler (Ed: Ağaoğlu, S., Gerçekçioğlu, R.). Tomurcukbağ Ltd. Şti. Eğitim Yayınları No: 1. Sayfa: 57-117.

Vazquez P, Holquin G, Duente ME, Lopez-Cortes A, Bashan Y 2000. Phosphate solubilizing microorganisms associated with rhizosphere of mangroves in a semiarid coastal lagoon. Biol., Fert., Soils, 30: 460-468.

Wani PA, Khan MS 2010. Bacillus species enhance growth parameters of chickpea (Cicer arietimum L.) in chromium stressed soils. Food Chem. Toxicol, 48: 3262-3267.

Xu J, Kloepper JW, McInroy J, Hu CH, Bonilla R 2011. Isolation and characterization of nitrogen-fixing and phosphate-solubilizing bacteria from Arundo donax L. (giant reed). Proceedings of the 2nd Asian PGPR Conference, Beijing, China, pp:409-415.

Yasmin F, Othman R, Sijam K, Saad MS 2007. Effect of PGPR inoculation on growth and yield of sweet potato. Journal of Biological Sciences, 7(2): 421-424. 